\title{
ДОСЛІДЖЕННЯ СТАНУ ОРГАНІЗАЦІЇ ЗАБЕЗПЕЧЕННЯ НАСЕЛЕННЯ ЛІКАРСЬКИМИ ЗАСОБАМИ В РОКИ НЕЗАЛЕЖНОСТІ УКРАЇНИ - СТАНОВЛЕННЯ ФАРМАЦЕВТИЧНОГО РИНКУ
}

\author{
В. О. Борищук, О. С. Соловйов, Т. М. Краснянська', І. В. Клименко, \\ С. В. Аугунас, Ю. М. Григорук ${ }^{2}$, О. В. Кирпач \\ Національна медична академія післядипломної освіти імені П. Л. Шупика \\ ${ }^{1}$ Українська військова медична академія \\ ${ }^{2}$ Вінницький національний медичний університет імені М. І. Пирогова
}

\begin{abstract}
У роботі представлено вивчення відповідності діючої законодавчої та нормативної баз потребам розвитку фармацевтичної галузі, аналіз становлення українського фрармацевтичного ринку, стан забезпечення лікарськими засобами у відповідності з європейськими вимогами та рекомендаціями ВООЗ.

Встановлено, що з усіх 75 досліджуваних аптек у різних регіонах країни (Закарпатська, Рівненська, Хмельницька, Херсонська обл.) лікарські засоби відпускаються без рецептів лікарів. За 2014 рік фрармацевтичний ринок, порівняно $з$ попередніми роками, зріс на 14 \% та його обсяг склав 36 млрд грн. Виробники ліків здійснюють агресивний маркетинг і порушують правила рекламування. Серед важливих проблем вимагають вдосконалення законодавча та нормативна бази, що потребують дій на урядовому рівні в забезпеченні економічної доступності лікарських засобів для усіх верств населення.
\end{abstract}

Ключові слова: фармацевтичний ринок, дженерики, ціни на лікарські препарати, фрізична та економічна доступність ліків.

\section{ИССЛЕДОВАНИЕ СОСТОЯНИЯ ОРГАНИЗАЦИИ ОБЕСПЕЧЕНИЯ НАСЕЛЕНИЯ ЛЕКАРСТВЕННЫМИ СРЕДСТВАМИ В ГОДЫ НЕЗАВИСИМОСТИ УКРАИНЫ - СТАНОВЛЕНИЕ ФАРМАЦЕВТИЧЕСКОГО РЫНКА}

\author{
В. А. Борищук, А. С. Соловьев, Т. М. Краснянская ${ }^{1}$ И. В. Клименко, \\ С. В. Аугунас, Ю. М. Григорук ${ }^{2}$, А. В. Кирпач \\ Национальная медицинская академия последипломного образования имени П. Л. Шупика \\ 1 Украинская военная медицинская академия \\ ${ }^{2}$ Винницкий национальный медицинский университет имени М. И. Пирогова
}

\begin{abstract}
Целью работы было изучение соответствия действующих законодательной и нормативной баз потребностям развития фармацевтической отрасли, анализ становления украинского фармацевтического рынка, состояние обеспечения лекарственными средствами в соответствии с европейскими требованиями и рекомендациями ВОЗ.

Для исследования использовались архивные материалы, публикации в научных изданиях и средствах массовой информации, изучались законодательные и нормативные акты, регулирующие фармацевтическую деятельность, проводилось анкетирование граждан. Применялись методы системно-логического, сравнительно-аналитического анализа и осуществлялись собственные исследования.

За 22 года становления украинской государственности были созданы институты: Фармакологический колледж, Фармакопейный комитет, Государственная служба по контролю качества лекарственных средств, которые транспортировались в другие институты. Приняты важнейшие законодательные акты: Закон Украины «О лекарственных средствах», Закон Украины «О малой приватизации», Закон Украины «О большой приватизации» и др., которые способствовали становлению и развитию фармацевтического рынка.

В сравнении с 1990 годом в 2,5 раза возросла аптечная сеть и уже в 2013 году в стране функционировало 15566 аптек, в т. ч. 3025 - в сельской местности. Характерной особенностью становления фармацевтического рынка в Украине было создание мощных собственных аптечных сетей регионального и всеукраинского значения, что коренным образом отличается от состояния этой проблемы в Европейских странах, где законодательством разрешается иметь в собственности одну или две аптеки. Становление фармацевтического рынка способствовало в 8 раз увеличению номенклатуры лекарственных средств, которая сейчас составляет свыше 20 тысяч наименований, 92,4 \% из которых
\end{abstract}

(C) В. О. Борищук, О.С.Соловйов, Т. М. Краснянська та ін. 


\title{
МЕДИЧНА ІНФОРМАТИКА TA ІНЖЕНЕРІЯ
}

дженерики. В соответствии с публикациями в Украине отсутствует около 32 \% молекул препаратов, необходимых для проведения лечебного процесса, а 40 \% исследуемых препаратов не доказана. В Украине существует проблема неконтролируемого оборота и потребления лекарственных средств. Самолечение приобрело широкое распространение: 82 \% украинцев занимаются самолечением даже при легком недомогании.

Установлено, что из всех 75 исследуемых аптек в разных регионах страны (Закарпатская, Ровненская, Хмельницкая, Херсонская обл.) лекарственные средства отпускаются без рецептов врачей. За 2014 год фармацевтический рынок в сравнении с предыдущими годами вырос на 14 \% и его объем составил 36 млрд грн. Производители лекарств осуществляют агрессивный маркетинг и нарушают правила рекламирования лекарств. Среди важных проблем, требующих совершенствования законодательной и нормативной баз, которая нуждается в действиях на правительственном уровне в обеспечение экономической доступности лекарственных средствах всех слоев населения.

Ключевые слова: фармацевтический рынок, дженерики, цена на лекарственные препараты, фризическая и экономическая доступность лекарств.

\section{RESEARCH OF CONDITION OF PUBLIC DRUG ASSISTANCE DURING INDEPENDENCE YEARS OF UKRAINE - FORMATION OF PHARMACEUTICAL MARKET}

\author{
V. O. Boryshchuk, O. S. Solovyov, T. M. Krasnianska', I. V. Klymenko, \\ S. V. Auhunas, Yu. M. Hryhoruk ${ }^{2}$, O. V. Kyrpach \\ P. L. Shupyk National Medical Academy of Postgraduate Education, Kyiv, Ukraine \\ ${ }^{1}$ Ukrainian Military Medical Academy, Kyiv, Ukraine \\ ${ }^{2}$ M. I. Pyrohov National Medical University, Vinnytsia, Ukraine
}

The aim of the research was to study the correspondence of existing legislative and regulatory requirements of the pharmaceutical industry development, the analysis of the formation of the Ukrainian pharmaceutical market, the condition of drug assistance according to European requirements and recommendations of the WHO.

For the study archival materials, publications in scientific journals, and mass media were used, laws and provisions regulating pharmaceutical activity were studied and a survey among citizens was conducted. Systematic and logical methods, analytical and comparative analysis were applied, and own researches were performed.

For 22 years of Ukrainian statehood formation the following institutes were created: Pharmacological College, Pharmacopoeia Committee and State Service for Quality Control of Drugs which were transported to other institutes. Important laws were adopted: the Law of Ukraine "On Medicines», the Law of Ukraine "On small-scale privatization», the Law of Ukraine "On large-scale privatization» and others, which contributed to the formation and development of the pharmaceutical market.

In comparison with 1990 the amount of drugstore chains increased two and a half times and in 2013 in the country already worked 15566 drugstores, including 3025 in villages. Specific peculiarity of pharmaceutical market formation in Ukraine was the creation of powerful own regional and all-Ukrainian drugstore chains, that is greatly different from such situation in EU countries, where the legislation allows to have only one or two drugstores. As the result of pharmaceutical market formation the drugs nomenclature increased eight times and now makes up more than 20000 names, including $92.4 \%$ generic drugs. According to publications, Ukraine lacks about $40 \%$ of drug molecules needed for medical treatment, and $30 \%$ of studied drugs are not proved. There is the problem of uncontrollable turnover and drugs consumption in Ukraine. Self-treatment is widespread today: $82 \%$ of Ukrainians prescribe medicines by themselves even when they feel a little unwell.

Among all examined 75 drugstores in different regions (Zakarpattya, Rivne, Khmelnytsk, Kherson etc.) people can get drugs without prescription. During 2014 the pharmaceutical market in comparison with previous year rose by $14 \%$ and its income made up 36 billion UAH. Drug producers perform aggressive marketing and break rules of drugs advertising. Among important problems that require the improvement of legislative and regulatory base at governmental level concerning the economic drug assistance for all population groups.

Key words: pharmaceutical market, generic drugs, price of drugs, physical and economic affordability of medicines.

Вступ. За роки становлення української державності фармацевтична галузь країни вступила в ринкові відносини, що принесло багато позитивного, зокрема в десятки разів збільшилась номенклатура лікарських засобів та їх ресурси.

Разом із тим, особливо в останній час, відмічаються надзвичайно гострі проблеми у цій сфері. Насамперед це фізична і економічна недоступність в отриманні лікарських засобів значною кількістю громадян України, що пов'язано з невідповідністю нормативно-правової бази щодо нераціонального розміщення аптечної мережі в містах; недостатньою кількістю аптечних закладів (підприємств) у сільській місцевості; збільшенням в 2-3 рази цін на ліки; низьким рівнем платоспроможності населення; надто надмірною опікою з боку держави 
і одночасною нерегульованістю ряду аспектів фармацевтичної діяльності; застарілими законодавчими та нормативними актами або їх відсутністю. I, що надзвичайно важливо, відсутня цілісна державна політика щодо організації забезпечення населення лікарськими засобами, яка відповідала б законодавству країн Європейського Союзу (ЄС). Означена низка проблем іє предметом нашого дослідження.

Мета роботи: вивчення відповідної діючої законодавчої і нормативної бази, потреб розвитку фармацевтичної допомоги населенню, становлення фармацевтичного ринку в країні, стану забезпечення населення лікарськими засобами відповідно Настанови 2001/83 СС та рекомендацій ВООЗ.

Матеріали та методи дослідження. В роботі використовувались архівні матеріали, публікації у наукових виданнях та засобах масової інформації, законодавчі та нормативні акти, що регулюють фармацевтичну діяльність, результати анкетування громадян - відвідувачів аптек. Задіяні валідні методи системно-логічного та порівняльноаналітичного аналізу власних досліджень.
Результати дослідження та їх обговорення. Iз здобуттям у 1991 році державної самостійності, в Україні відбулися історичні зміни в суспільному і державному устрої, перехід від планової до ринкової економіки, в тому числі й у фармацевтичній галузі. За станом на 01.01.1992 р. в системі Міністерства охорони здоров'я функціонувало 6413 аптек, в тому числі в містах і селищах міського типу - 3629 , в сільській місцевості - 2 784. Кількість населення, яке обслуговувала одна аптека, залишилось на рівні 1990 р. - 7,9 тис., у тому числі в містах і селищах міського типу - 9,4 тис., а в сільській місцевості 6 тис. чол. (табл. 1,2$)[1,2]$.

Тобто на той період, в цілому по Україні, був досягнутий нормативний показник - число жителів на одну аптеку, який встановлено наказом Міністерства охорони здоров'я України від 09.02.1981 р. № 69. Фактично, на початку 90-х років минулого століття було досягнуто оптимальне забезпечення населення аптечними закладами, що створювало умови для фізичної доступності населення до лікарських засобів (табл. 2) [1].

Таблиця 1. Аналіз аптечної мережі в Україні станом на 01.01.1992 року

\begin{tabular}{|c|c|c|c|}
\hline \multirow{2}{*}{ Найменування областей } & \multicolumn{3}{|c|}{ Аптеки } \\
\hline & всього на 01.01.1992 p. & в містах & в сільській місцевості \\
\hline Вінницька & 324 & 107 & 217 \\
\hline Волинська & 137 & 65 & 72 \\
\hline Дніпропетровська & 315 & 204 & 111 \\
\hline Донецька & 582 & 516 & 66 \\
\hline Житомирська & 227 & 97 & 130 \\
\hline Закарпатська & 179 & 81 & 98 \\
\hline Запорізька & 247 & 140 & 107 \\
\hline Івано-Франківська & 183 & 91 & 92 \\
\hline Київська & 272 & 112 & 160 \\
\hline Кіровоградська & 183 & 88 & 95 \\
\hline Автономна республіка Крим & 238 & 137 & 101 \\
\hline Луганська & 374 & 311 & 63 \\
\hline Львівська & 339 & 219 & 120 \\
\hline Миколаївська & 173 & 76 & 97 \\
\hline Одеська & 329 & 174 & 155 \\
\hline Полтавська & 294 & 106 & 188 \\
\hline Рівненська & 142 & 65 & 77 \\
\hline Сумська & 233 & 97 & 136 \\
\hline Тернопільська & 164 & 79 & 85 \\
\hline Харківська & 358 & 250 & 108 \\
\hline Херсонська & 167 & 85 & 82 \\
\hline Хмельницька & 200 & 89 & 111 \\
\hline Черкаська & 207 & 81 & 126 \\
\hline Чернігівська & 114 & 55 & 59 \\
\hline Чернівецька & 207 & 82 & 125 \\
\hline Київ & 191 & 191 & - \\
\hline Кривий Ріг & 34 & 31 & 3 \\
\hline Всього & 6413 & 3629 & 2784 \\
\hline
\end{tabular}


Таблиця 2. Якісні характеристики показників матеріальної бази аптечної мережі та відповідність ї до нормативів станом на 01. 01. 1992 р.

\begin{tabular}{|c|c|c|c|c|c|c|}
\hline \multirow[b]{2}{*}{ Найменування областей } & \multirow[b]{2}{*}{ В цілому } & \multicolumn{2}{|c|}{ В тому числі } & \multicolumn{3}{|c|}{ По відношенню до користувачів (\%) } \\
\hline & & $\begin{array}{l}\text { в містах і } \\
\text { селищах } \\
\text { міського } \\
\text { типу }\end{array}$ & $\begin{array}{l}\text { в сільській } \\
\text { місцевості }\end{array}$ & в цілому у \% & $\begin{array}{l}\text { в містах і } \\
\text { селищах } \\
\text { міського } \\
\text { типу }\end{array}$ & $\begin{array}{l}\text { в сільській } \\
\text { місцевості }\end{array}$ \\
\hline Вінницька & 5,9 & 8,0 & 4,8 & 69,4 & 80,0 & 73,8 \\
\hline Волинська & 7,8 & 8,3 & 7,3 & 91,8 & 83,0 & 112,3 \\
\hline Дніпропетровська & 9,3 & 11,8 & 4,7 & 109,4 & 118,0 & 72,3 \\
\hline Донецька & 8,8 & 9,3 & 6,0 & 103,5 & 93,0 & 92,3 \\
\hline Житомирська & 6,6 & 8,4 & 5,3 & 77,6 & 84,0 & 81,5 \\
\hline Закарпатська & 7,1 & 6,5 & 7,5 & 83,5 & 65,0 & 115,4 \\
\hline Запорізька & 8,5 & 11,4 & 4,6 & 100,0 & 114,0 & 70,8 \\
\hline Івано-Франківська & 7,8 & 6,7 & 8,9 & 91,8 & 67,0 & 136,9 \\
\hline Київська & 7,1 & 9,5 & 5,5 & 83,5 & 95,0 & 84,6 \\
\hline Кіровоградська & 6,7 & 8,5 & 5,1 & 78,8 & 83,0 & 78,5 \\
\hline Автономна республіка Крим & 9,0 & 9,9 & 7,7 & 105,9 & 99,0 & 118,5 \\
\hline Луганська & 7,7 & 8,0 & 6,7 & 90,6 & 80,0 & 93,8 \\
\hline Львівська & 8,1 & 7,5 & 9,7 & 95,3 & 75,0 & 140,0 \\
\hline Миколаївська & 7,8 & 11,7 & 4,7 & 91,8 & 117,0 & 72,3 \\
\hline Одеська & 8,0 & 9,9 & 5,7 & 94,1 & 99,0 & 87,7 \\
\hline Полтавська & 6,0 & 9,4 & 4,0 & 70,6 & 94,0 & 61,5 \\
\hline Рівненська & 8,3 & 8,4 & 8,1 & 97,6 & 84,0 & 124,6 \\
\hline Сумська & 6,1 & 9,3 & 3,9 & 71,8 & 93,0 & 60,0 \\
\hline Тернопільська & 7,1 & 6,2 & 8,0 & 83,5 & 62,0 & 123,1 \\
\hline Харківська & 8,9 & 10,0 & 6,2 & 104,7 & 100,0 & 95,4 \\
\hline Херсонська & 7,6 & 9,2 & 5,9 & 89,4 & 92,0 & 90,8 \\
\hline Хмельницька & 7,6 & 8,4 & 6,9 & 89,4 & 84,0 & 106,2 \\
\hline Черкаська & 7,4 & 10,1 & 5,6 & 87,0 & 101,0 & 96,2 \\
\hline Чернігівська & 6,8 & 9,4 & 5,0 & 80,0 & 94,0 & 76,9 \\
\hline Чернівецька & 8,3 & 7,3 & 9,2 & 97,6 & 73,0 & 141,5 \\
\hline Київ & 13,9 & 13,9 & - & 162,5 & 139,0 & - \\
\hline Кривий Ріг & 9,1 & 10,0 & 5,7 & 107,0 & 100,0 & - \\
\hline м. Севастополь & 12,0 & 12,5 & 6,7 & 141,2 & 125,0 & 103,1 \\
\hline Всього & 7,9 & 9,4 & 6,0 & 100 & 100 & 100 \\
\hline Норматив & 8,5 & 10,0 & 6,5 & 100 & 100 & 100 \\
\hline
\end{tabular}

В таблиці 2 наведені дані про кількість населення, яке обслуговувала одна аптека, станом на 01.01.1992 р., по відношенню до нормативів. Одночасно, саме у цей період, в Україні були прийняті Закони «Про малу приватизацію», «Про велику приватизацію», ряд інших законодавчих актів, згідно з якими дозволялась комерційна діяльність у фармацевтичній галузі, передбачалось роздержавлення аптечної мережі, створення приватних аптек, інших форм власності та передбачався вільний доступ в країну імпортних лікарських засобів і найголовніше, дозволялось формування цін на ліки юридичним і фізичним особам, власникам аптек [9].
Розпочалась, власне кажучи, «золота лихоманка». В українську фармацію були залучені особи, що мали досвід у торгівлі і вбачали перспективи легкого збагачення. Аптеки стихійно, нераціонально, хаотично відкривалися повсюди, навіть в підвальних і напівпідвальних приміщеннях, одночасно зменшувалась аптечна мережа в сільській місцевості, як нерентабельна. Одночасно слід підкреслити, що у 2013 р. вже функціонували 15566 аптек, тобто аптечна мережа, порівняно з 1990 роком, збільшилась у 2,5 раза $[8,9]$. В Україні у сільській місцевості проживає майже третина населення, проте там розміщена лише четверта частина аптечних закладів, через які відпускається всього $10 \%$ 
загальноукраїнського об'єму роздрібної реалізації лікарських засобів. За 2011-2013 рр. в сільській місцевості було закрито 717 аптек [10, 15].

Характерною особливістю становлення фармацевтичного ринку є створення об'єднань та фірм приватних аптечних мереж: «Фалбі», згодом «Лекхім», «Аптеки доброго дня», «Аптеки низьких цін» та. ін. Однак, практично була порушена цілісна система забезпечення населення лікарськими засобами, а держава фактично втратила вплив на здійснення соціальної політики у цій важливій соціально-орієнтованій сфері діяльності.

Незважаючи на те, що українська влада декларувала своє прагнення до Європейських цінностей і стандартів, процеси, які відбулися при роздержавленні і приватизації аптечних закладів, здебільшого не прискорили ці процеси в адаптації вимог до стандартів Свропейського Союзу (СС). Так, у жодній країні ЄС немає відокремлених об'єднань приватних аптечних мереж, які фактично нав'язували суспільству власне розуміння організації забезпечення населення лікарськими засобами.

У більшості країн Європи, зокрема в Німеччині, Іспанії, Франції, Греції, Нідерландах - громадянин може бути власником лише однієї аптеки, мати фармацевтичну освіту і керувати нею. В Італії фармацевт може мати у власності не більше 2-х аптек. В Швеції немає приватної власності на аптеки. У Великобританії - половина приватних аптек належить фармацевтам. В Естонії - 90 \% аптек приватизовані, власником аптеки може бути тільки фармацевт, i, що надзвичайно важливо, кількість аптек в конкретному населеному пункті обмежена, що забезпечує раціональне розміщення аптечної мережі. Наприклад, в Австрії, передбачено, що одна аптека може обслуговувати 6 тис. населення, а у випадках, коли цей критерій складає 5,5 тис. дозвіл (ліцензію) на відкриття аптеки не видають. Безумовно позитивним у цей період було створення в Україні важливих інститутів, підпорядкованих Міністерству охорони здоров'я України, зокрема, Державної інспекції з контролю якості лікарських засобів, Фармакологічного комітету, Фармакопейного комітету, які й дотепер впливають на розвиток подій на фармацевтичному ринку України.

Надзвичайно важливим $€$ факт нормативноправового регулювання фармацевтичного ринку. У 1991 році було прийнято базовий Закон України «Про лікарські засоби». Слід відмітити, що з часу прийняття цього закону минуло майже 19 років, до нього було внесено більше 5 змін. На цей час ряд норм цього закону застарілі і втратили силу, тому $\epsilon$ необхідність прийняття нової редакції 3 конкретними змінами закону в цій сфері. За роки незалежності значно зросла кількість зареєстрованих в Україні лікарських засобів. За різними даними, у 2013 році зареєстровано близько 22 тис. найменувань лікарських засобів [8]. Незважаючи на те, що фармацевтичний ринок України на сьогодні досить насичений, а окремими фармакологічними групами - перенасичений, аналіз асортименту зареєстрованих в Україні лікарських засобів, порівняно з Британським національним формуляром (який є золотим стандартом формуляра країн (С), показав, що в Україні теоретично неможливо надавати медичну допомогу у вигляді фармакотерапії за європейськими стандартами, оскільки в нашій країні відсутні близько 32 \% молекул, необхідних для лікувального процесу. В обігу на фармацевтичному ринку з Британського формуляра, всього близько 40 \% молекул, до того ж, представлені в інших лікарських формах, ніж це передбачено у відповідних європейських документах [5, 6, 12, 13].

При формуванні в Україні Національного переліку основних лікарських засобів відповідно до рекомендацій ВООЗ також виявилось, що в нашій країні відсутні близько 30 \% препаратів, які мають використовуватись у лікувальному процесі [13]. Деякі препарати реєструються без доказової бази щодо їх ефективності. Згадані вище 30 \% препаратів, що мають використовуватись у лікувальному процесі за міжнародними стандартами, але відсутні на ринку України, за рекомендацією українських спеціалістів замінені на такі, що є на українському ринку і наближені за властивостями до тих, які за доказовою медициною мають застосовуватись в лікувальному процесі. Тобто в Україні 30 \% препаратів, які застосовуються в лікувальному процесі відповідно до міжнародних стандартів, не мають доведеної ефективності [5, 6, 13]. Основну масу лікарських засобів, присутніх на українському фармацевтичному ринку, становлять дженерики, тобто ліки на основі активних інгредієнтів, строк патенту який уже закінчився. За кордоном частка дженериків займає близько половини всього медикаментозного ринку. У США обсяг їх продажу становить $30 \%$, в Німеччині - 50-70\%, в Україні за різними даними - 80-93\% [6, 12, 13].

В Україні існує проблема неконтрольованого обігу, i, особливо, ненормоване вживання лікарських засобів, оскільки діяльність фармацевтичної галузі 
спрямована переважно на отримання прибутків $[5,6,7,11]$. Практично відсутній контроль за тим, які саме ліки застосовують громадяни, чи є ефект від лікування, чи є наявний позитивний вплив на стан здоров'я. Значна частина лікарських засобів реалізується в Україні без рецептів. Самолікування набуває все більшого розповсюдження [12]. Наші дослідження в аптеках м. Києва системи «Низьких цін», «Лекхім», «Доброго дня», КП «Фармація» встановили, що у багатьох досліджуваних аптеках рецептурні лікарські препарати відпускаються без рецепта лікаря.

Фармацевтичний ринок в 2014 році зріс, порівняно з минулими роками, на $14 \%$, його об'єм складає 36 млрд. грн, 65 \% реалізованих лікарських препаратів - українського виробництва; за прогнозами, у 2015 році приріст складатиме 24,6 \% [2]. Слід відмітити, що щорічний зріст продаж лікарських засобів відбувається також внаслідок агресивної промоції препаратів серед лікарів та їх реклами в засобах масової інформації. За даними досліджень І. О. Ткачука, Л. Г. Новікової, майже $40 \%$ реклами медичних препаратів допускають порушення діючих правил, значна кількість препаратів рекламується як єдиний засіб для лікування того чи іншого захворювання, що призводить до самолікування і безконтрольного споживання лікарських засобів. У тексті реклами та і при проведенні промоції представники виробників вказують лише на переваги і властивості препарату, перебільшують позитивний ефект та створюють враження про його унікальність і оригінальність, все це сприяє формуванню у споживача потреби його придбання та використання [11].

Ряд виробників при просуванні ліків на ринок не дотримуються рекомендацій ВОО3 і ЄС - етичних норм і правил. Деякі виробники постачають ліки без необхідної для пацієнта інформації щодо умов зберігання ліків та їх вживання, що передбачено Директивою СС 92/96 та вітчизняними нормативними вимогами $[11,12,13]$.

Одна з основних стратегій, що використовуються виробниками для розширення фармацевтичного ринку, спрямована на «продукування» нових хвороб населення шляхом вживання фармацевтичних препаратів. Більшість лікарських засобів, які призначаються і приймаються мільйонами пацієнтів, сприяють тому що, безконтрольне вживання препаратів викликають безліч нових хвороб - в результаті властивих їм відомих довгострокових побічних ефектів [3].
Вищеозначені обставини, що склалися на українському ринку, сприяють широкому розповсюдженню самолікування населення, яке в країні набуло величезних масштабів. За період з 1995 по 2012 роки номенклатура лікарських засобів, дозволених до відпуску без рецепта лікаря, зросла майже у 20 разів (1995 р. - 210 найменувань; 2012 р. - 3755). За даними досліджень, 82 \% українців займаються самолікуванням при легкому нездужанні. Поряд 3 цим, необгрунтоване призначення лікарських засобів, поліпрагмазія чинять непоправну шкоду організму людини. Безконтрольне вживання ліків, фармакоманія - чинять потужну негативну антроекологічну дію на організм людини, тому їм потрібно своєчасно запобігати та уникати [7]. Всі лікарські засоби, присутні на фармацевтичному ринку, крім терапевтичної дії мають побічну дію, в тому числі так звану відстрочену (приховану) побічну дію, що може проявлятись через роки $\mathrm{i}$ навіть у наступних поколіннях [3, 14].

Наступною надзвичайно важливою проблемою $\epsilon$ економічна недоступність громадянам лікарських засобів. 3 року в рік держава фінансує забезпечення медикаментами 40 \% від потреби, а в 2014 році воно скоротились в 2 рази, внаслідок девальвації гривні і введення ПДВ на ліки. Це означає, що онкологічні хворі, хворі з муковісцидозом, фенілкетонурією, гемофілією, ВІЛ/СНІДом - залишаться без державної підтримки в забезпеченні життєво важливими препаратами [4], адже, за даними публікацій, соціальна структура суспільства наступна: 1 \% - заможне населення, 80 \% - бідні верстви населення, які примітивно виживають, 3 -4 \% населення відповідають середньому класу. В Західних суспільствах - середній клас складає 70-80\% населення. У зв'язку з тим, що з початку 2015 року удвоє знецінилась гривня та введений 7 \% ПДВ на ліки, в кінцевому результаті, при відпуску ліків із аптеки ціна зростає до $20 \%$ - імпортні ліки стають не тільки недоступні мільйонам пенсіонерів, але й пересічним громадянам - бідним верствам населення і тим, що відповідають середньому класу [4].

Висновки. 1. Проведені дослідження засвідчують недосконалість діючої законодавчої та нормативної бази у фармацевтичній галузі, що потребує приведення її до європейських стандартів і вимог.

2. В Україні необхідне вироблення та поетапна реалізація послідовної державної політики щодо розміщення аптечної мережі, фізичної та еконо- 
мічної (цінової) доступності лікарських засобів для всіх верств населення, запобігання самолікуванню та обмеження впливу фармацевтичних компаній, що в неправомірний спосіб здійснюють агресивну маркетингову діяльність.

\section{Література}

1. Анализ финансово-хозяйственной деятельности аптечной сети предприятий Украины в 1991 г. (инстр.метод. матер.). - К. : Изд. Научно-производственное объединение «Укрфармация» и Украинского научноисследовательского центра фармации, 1992. - 82 с.

2. Громовик Б. П. Сучасні аспекти фармацевтичної практики в Україні / Б. П. Громовик, А. В. Горілик [та ін.]. - Львів, 2014. - 386 с.

3. Дроговоз С. М. Побочное действие лекарств / С. М. Дроговоз. - Харьков : СИМ, 2010. - 480 с.

4. За каждой строкой в бюджете на медицину стоит чьято жизнь // «Голос Украины». - 2014. - № 116. - С. 1.

5. Дослідження тенденцій лікарських препаратів - дженериків / 3. М. Мнушко, О. Ю. Вінник, І. В. Пеступн [та ін.] // Фармац. журн. - 1998. - № 4. - С. 19-25.

6. Дослідження тенденцій ринку лікарських препаратів / 3. М. Мнушко, О. Ю. Вінник, І. В. Пеступн [та ін.] // Фармац. журн. - 2013. - № 6. - С. 13-25.

7. Пушак К. І. Актуальні проблеми фармацевтичної профілактики / К. І. Пушак, І. І. Даценко, Б. Л. Парновський [та ін.] // Фармац. журн. - 2009. - № 1. - С. 3-7.

8. Рост фармацевтического рынка // Голос Украины. 2014. - № 8. - C. 17.
3. На державному рівні доцільно запровадити реєстрацію цін та максимального рівня націнки на всі лікарські препарати.

9. Загальне науково-практичне обгрунтування формування основ галузевого права у системі обігу лікарських засобів. Повідомлення II / О. С. Соловйов, О. П. Гудзенко, М. С. Пономаренко [та ін.] // Фармац. журн. - 2013. - № 6. - С. 3-13.

10. Силивончик А. В. Ласточкино гнездо / А. В. Силивончик // Журнал Бизнес. - 2014. - № 12-13. C. 57-58.

11.Ткачук I. О. Етичні норми регулювання фармацевтичного бізнесу // І. О. Ткачук, Л. Т. Новікова // Фармац. журн. - 2008. - № 1. - С. 17-19.

12. Чумак В. Т. Доступність лікарських засобів в Україні / В. Т. Чумак // Рациональная фармакотерапия. - 2009. - № 4. - C. 1-4.

13. Чумак В. Т. Реєстрація лікарських засобів: навіщо нині намагаються змінити систему / В. Т. Чумак // Еженедельник АПТЕКА. - 2014. - № 92. - С. 12-13.

14. Шибаева А. Инфраструктура аптечного рынка Украины / А. Шибаева // Еженедельник АПТЕКА. 2013. - № 1. - С. 9-11.

15. Яншин У Аптека на колесах / У. Яншин, В. Саранчук // Зеркало недели. - 2014. - № 27. - С. 12-13. 